\title{
Bridging barriers: a comparative look at the blood-brain barrier across organisms
}

\author{
Natasha M. O'Brown, ${ }^{1}$ Sarah J. Pfau, ${ }^{1}$ and Chenghua Gu \\ Department of Neurobiology, Harvard Medical School, Boston, Massachusetts 02115, USA
}

\begin{abstract}
The blood-brain barrier (BBB) restricts free access of molecules between the blood and the brain and is essential for regulating the neural microenvironment. Here, we describe how the BBB was initially characterized and how the current field evaluates barrier properties. We next detail the cellular nature of the $B B B$ and discuss both the conservation and variation of $B B B$ function across taxa. Finally, we examine our current understanding of mouse and zebrafish model systems, as we expect that comparison of the $\mathrm{BBB}$ across organisms will provide insight into the human BBB under normal physiological conditions and in neurological diseases.
\end{abstract}

\section{History of the BBB}

\section{Concept of a barrier}

The existence of a functional blood-brain barrier (BBB) was initially characterized in the late 19th and early 20th centuries by a number of studies that used vital dyes and central nervous system (CNS)-impermeable compounds as tracers to assess brain blood vessel permeability. First, Ehrlich (1885) injected alizarin blue subcutaneously or intravenously in adult rats and noted that while the blue tracer was generally detected in tissues throughout the body, it was always excluded from the CNS. Although Ehrlich (1885) was the first to describe the phenomenon of CNS tracer exclusion, the term "blood-brain barrier" was coined several decades later, following the work of Lewandowsky (1900), Goldmann $(1909,1913)$, and Stern and Gautier $(1918,1921)$. Lewandowsky (1900) showed that the poisons strychnine and sodium ferrocyanide had higher lethal doses when injected subcutaneously or intravenously than when injected intrathecally into the cerebrospinal fluid (CSF) in dogs, cats, rabbits, and sheep. These observations led him to speculate that the brain vasculature limits the poisons' access to the brain and thus toxicity when administered pe-

[Keywords: blood-brain barrier; evolution; mouse; zebrafish]

${ }^{1}$ These authors contributed equally to this work.

Corresponding author: chenghua_gu@hms.harvard.edu

Article is online at http://www.genesdev.org/cgi/doi/10.1101/gad.309823. 117. ripherally (Lewandowsky 1900). Goldmann (1909, 1913) showed that trypan blue tracer was excluded from rodent and rabbit brains when injected into the periphery (Goldmann 1909) but not when injected intrathecally (Goldmann 1913), providing further evidence for the existence of a barrier between the brain and the blood. Finally, Stern and Gautier $(1918,1921)$ performed studies in dogs, cats, rabbits, and guinea pigs. They studied a number of compounds that could be detected after intravenous injection, including antibodies and tracer dyes (e.g., India ink and eosin) or chemicals with known effect on the nervous system (e.g., morphine and curare). They tracked the passage of these compounds from the blood into the brain by measuring the concentration of each compound in both blood and CSF after injection and found that while some compounds were present in both the blood and the CSF (such as morphine), others (such as India ink) were only detected in the blood and not in the CSF (Stern and Gautier 1918, 1921). Based on their findings, the investigators concluded that a barrier existed that separated the blood from the brain. Stern and Gautier $(1918,1921)$ were the first to use the term "barrier" to describe this observation (Stern and Gautier 1918) and later aptly proposed that this barrier be called the "blood-brain barrier" (Stern and Gautier 1921).

\section{Cellular nature of the barrier}

Several decades later, the advent of electron microscopy (EM) permitted the identification of the cell type responsible for the vertebrate BBB. Initial studies speculated that astrocytes, a CNS-specific glial cell type in direct contact with brain blood vessels, were the effective site of the BBB (Gray 1961). Indeed, some organisms, such as the fruit fly Drosophila melanogaster, have a glial barrier between the neuropil and the circulatory system (Limmer et al. 2014). However, Reese and Karnovsky (1967) found that the integrity of the mammalian BBB was attributable to key characteristics of CNS capillary endothelial cells. By injecting the enzyme horseradish peroxidase (HRP) into

(C) 2018 O'Brown et al. This article is distributed exclusively by Cold Spring Harbor Laboratory Press for the first six months after the full-issue publication date (see http://genesdev.cshlp.org/site/misc/terms.xhtml). After six months, it is available under a Creative Commons License (Attribution-NonCommercial 4.0 International), as described at http:// creativecommons.org/licenses/by-nc/4.0/. 
the circulation of mice, they observed the confinement of HRP within the blood vessel lumina in the brain, as evidenced by the appearance of an electron-dense product of the peroxidase after incubation with the substrate $3,3^{\prime}$-diaminobenzidine (DAB). These results were in accordance with earlier tracer studies such as those described above. However, by using EM to examine the subcellular localization of the electron-dense HRP reaction product, they found that the passage of HRP from the circulation into the neuropil was restricted at tight junction "kissing points," which are regions where two outer leaflets of adjacent endothelial cell membranes are closely apposed. In contrast, HRP had been observed to pass through some endothelial cell tight junctions in the periphery (Karnovsky 1967). They also noted that there were negligible levels of pinocytotic vesicles within brain endothelial cells (Reese and Karnovsky 1967). Thus, Reese and Karnovsky (1967) attributed barrier function to the presence of specialized tight junctions in CNS endothelial cells. Evidence for an endothelial cell barrier was further bolstered by the experiments of Brightman and Reese (1969). By perfusing HRP in mouse brain ventricles, introducing HRP directly into the brain parenchyma, they revealed that HRP went beyond the astrocytic end feet but was halted by the tight junctions of brain endothelial cells at the abluminal side, further demonstrating that astrocytic end feet do not contribute physically to the barrier (Brightman and Reese 1969).

\section{Role of the CNS environment in BBB development}

Transplantation experiments performed during avian embryogenesis have shown that the neural environment provides critical barrier-inducing signals. To address whether barrier properties were innate to CNS endothelial cells or induced by external cues, Stewart and Wiley (1981a) transplanted nonvascularized quail brain tissue into the gut and nonvascularized quail somite tissue into the brains of 3-d chick embryos. They examined endothelial cell barrier properties $15 \mathrm{~d}$ later, after the grafted tissue was vascularized by the surrounding blood vessels. Importantly, after $15 \mathrm{~d}$, the transplanted brain tissue developed into mature neurons and glia, and the transplanted somites developed into a separate mesodermal mass containing cartilage, bone, feathers, and striated muscle. Injection of trypan blue revealed that the transplanted brain tissue in the gut contained blood vessels that restricted trypan blue to the vascular lumina, suggesting that functional barrier properties had been acquired, while the blood vessels penetrating nearby gut tissue readily leaked the trypan blue into the surrounding tissue. Conversely, the vessels in the brain-transplanted somitic graft readily leaked trypan blue, while the surrounding brain vasculature restricted the tracer within the blood vessels (Stewart and Wiley 1981a). Furthermore, when Stewart and Wiley (1981a) used EM to analyze the morphology of the cells in the brain grafts transplanted into the gut, they noted low levels of pinocytotic vesicles in the endothelial cells that vascularized the grafts. In contrast, endothelial cells of the somitic transplants in the brain contained numer- ous pinocytotic vesicles, an observation more characteristic of endothelial cells in peripheral tissues (Stewart and Wiley 1981a). Thus, this work demonstrated that barrier properties are not intrinsic to the endothelial cells but rather are acquired from the neural microenvironment. The brain microenvironment, which directly interacts with CNS endothelial cells, is comprised of neurons; mural cells, which include pericytes and vascular smooth muscle cells; and glial cells, such as astrocytes. All cell types in close proximity with neurons and the CNS vasculature are collectively referred to as the neurovascular unit (NVU), and the interactions between NVU cells influence barrier properties (Iadecola 2017; Kisler et al. 2017a).

\section{Evolutionary conservation of the function of the BBB}

\section{Defining $B B B$ permeability}

To determine whether an organism has a functional BBB, tracer leakage assays similar to those initially done as described above are the standard method to ascertain barrier properties. Briefly, a tracer is injected into the circulation of an organism, and leakage can be detected by analysis of brain tissue. A functional BBB restricts the tracer to the CNS blood vessels, excluding it from the brain parenchyma. However, if the barrier is not fully functional, the injected tracer will leak out of the blood vessels into the brain parenchyma.

The embryonic acquisition of BBB properties was determined by tracer leakage assays, as immature brain endothelial cells allow tracers to pass into the neuropil, while brain endothelial cells with barrier properties restrict tracers to the CNS vasculature (Saunders et al. 2012). In embryonic mouse brains, the spatio-temporal development of a functional BBB occurs gradually in a caudal-to-rostral, ventral-to-dorsal pattern, and, by embryonic day 15.5 (E15.5), the BBB is fully functional in the cortex (Ben-Zvi et al. 2014). Studies in rats show that the BBB also forms embryonically, with the tracer being confined within most of the brain vasculature at E15 (Daneman et al. 2010b). A similar spatio-temporal developmental pattern has also been observed in the blood-retinal barrier (BRB), which is a barrier physiologically analogous to the BBB. The primary plexus of the mouse retina becomes vascularized at the optic nerve head beginning at postnatal day 1 , and the BRB gradually forms in a proximal-to-distal fashion, with the BRB becoming fully functional throughout the retina at postnatal day 10 (Chow and Gu 2017). Beyond rodents, the development of the zebrafish BBB forms between 3 and $10 \mathrm{~d}$ post-fertilization (dpf) (Jeong et al. 2008; Tam et al. 2012; Fleming et al. 2013); however, the precise spatio-temporal profile for the development of the functional $\mathrm{BBB}$ in zebrafish has yet to be clearly elucidated.

There are several types of tracer leakage assays that are used to evaluate functional BBB properties.

Exogenous chemical tracers Fluorescently conjugated tracers are preferable tracers because they are nonreactive 
with serum proteins and are retained within the BBB vasculature under normal physiological conditions. Lysinefixable fluorescently conjugated dextrans are available in a wide range of molecular weights (from $3 \mathrm{kDa}$ up to $2000 \mathrm{kDa}$ ), permitting the assessment of leakage of both small and large tracers after perturbation of the BBB. In addition to dextrans, bovine serum albumin (BSA) is $\sim 66 \mathrm{kDa}$ and can also be used as an exogenous tracer when fluorescently conjugated. Furthermore, the small molecules Nhydroxysulfosuccinimide (NHS) biotin and biocytin are also suitable as tracers, as they are also normally retained within the BBB vasculature. NHS-biotin is an effective tracer because it is both small at $443 \mathrm{kDa}$ and reactive with amines. Previous work has demonstrated that deletion of the tight junction proteins Claudin- 5 or Lsr leads to increased BBB permeability specifically for small-molecular-weight substances, such as NHS-biotin (Nitta et al. 2003; Sohet et al. 2015). Fluorescently labeled biocytin has a slightly higher molecular weight: between $\sim 800$ and $1200 \mathrm{Da}$. Vital dyes such as Evans blue are less preferable for use as tracers due to their potential to bind directly to tissues, lack of specific albumin binding, and in vivo toxicity (Saunders et al. 2015). The use of tracers in a range of sizes is important when evaluating BBB permeability to characterize leakage phenotypes. Use of these wide-ranging tracers has been instrumental in not only determining the effects of genetic perturbations on barrier function (Armulik et al. 2010; Bell et al. 2010; Daneman et al. 2010b; Wang et al. 2012; Siegenthaler et al. 2013; BenZvi et al. 2014; Sohet et al. 2015; Winkler et al. 2015; Andreone et al. 2017; Cho et al. 2017; Chow and Gu 2017; Mazzoni et al. 2017) but also demarcating differences between disease pathophysiologies in murine models of Alzheimer's disease (Montagne et al. 2017) and stroke (Knowland et al. 2014).

Endogenous tracers BBB permeability has also been assessed without exogenous tracer injections by using immunofluorescence staining against endogenous serum proteins, which should normally be retained within the BBB vasculature, or studying transgenic animals with fluorescently tagged serum proteins. For example, immunostaining of endogenous plasma proteins such as IgG, $\mathrm{ApoB}$, and fibrinogen has been used to measure barrier permeability in both mouse and human tissues (Adams et al. 2007; Bell et al. 2010; Alvarez et al. 2011; Argaw et al. 2012; Winkler et al. 2015). When immunofluorescence for IgG or fibrinogen is used in conjunction with injected dextran tracers, the observed leakage phenotypes between dextrans and serum proteins are similar (Bell et al. 2010; Alvarez et al. 2011), further suggesting that both methods reliably reveal aberrant BBB permeability. In addition to in situ assessment of endogenous leakage, Western blots performed with the same serum antibodies have been used to measure whole-brain levels of IgG and fibrinogen in capillary-depleted brain homogenates (Bell et al. 2010; Winkler et al. 2015). While obscuring localization information, this method provides a quantitative measure for detecting overall amounts of endogenous leakage within the brain. In zebrafish, a transgenic line with a fluo- rescently labeled vitamin D-binding protein $(\sim 78 \mathrm{kDa})$, which is similar to the mammalian serum albumin, allows for in vivo live imaging of barrier functionality throughout development (Xie et al. 2010). Development of a mouse strain that expresses a fluorescently labeled serum protein could also facilitate in vivo examination of endogenous leakage in the mammalian BBB in the future.

Mass spectrometry imaging (MSI) Recent advances in the field of MSI now allow the identification of heme and pharmacological compounds outside of the blood vessels in mouse brains without the addition of fluorescent tracers, providing both localization and quantification of the concentration of the analyzed target (Liu et al. 2013; Parrish et al. 2015). With further advances in the technique, matrix-assisted laser desorption/ionization mass spectrometry imaging (MALDI)-MSI promises to reveal low levels of leakage in even smaller sample areas, which may make it a more approachable tool for analyzing BBB mutant mice with subtle BBB phenotypes in the future.

$H R P$ with EM EM analysis in conjunction with intravenous injection of the tracer HRP, which, with DAB, generates an electron-dense reaction product (the method that was originally used to demonstrate the presence of a vertebrate endothelial barrier) (Reese and Karnovsky 1967), remains the gold standard to reveal the subcellular mechanisms that lead to BBB dysfunction. Importantly, the presence of tight junction proteins alone is insufficient to determine whether intercellular junctions retain specialized BBB properties because peripheral endothelial cells also have tight junctions and express the same tight junction proteins. The function of specialized tight junctions can be assessed using small tracers or using EM with HRP, which can determine whether the HRP tracer is halted at the tight junctions between endothelial cells. This method can also detect aberrant vesicular trafficking, such as the presence of HRP-filled vesicles, which indicates increased transcytosis (Daneman et al. 2010b; BenZvi et al. 2014; Reyahi et al. 2015; Andreone et al. 2017; Chow and Gu 2017).

Dynamic contrast-enhanced magnetic resonance imaging (DCE-MRI) As many of the tracer leakage assays described above cannot be performed in humans, MRI is used to evaluate BBB permeability dynamics and leakage patterns in disease. The use of gadolinium together with MRI (DCE-MRI) enhances contrast and enables the measurement of regional vascular permeability dynamics at the BBB (Sweeney et al. 2018). Studies performed in mice have demonstrated that observations of leakage with MRI using gadolinium reflect leakage patterns observed after injection with exogenous tracers (Nitta et al. 2003; Navarathna et al. 2013; Li et al. 2014). DCEMRI has been used to show that BBB leakage is a characteristic of several neurodegenerative diseases in humans, including multiple sclerosis (Taheri et al. 2010; Gaitán et al. 2011; Ingrisch et al. 2012; Cramer et al. 2015; Montagne et al. 2015) and Alzheimer's disease (Montagne et al. 2015; van de Haar et al. 2016a, b). 


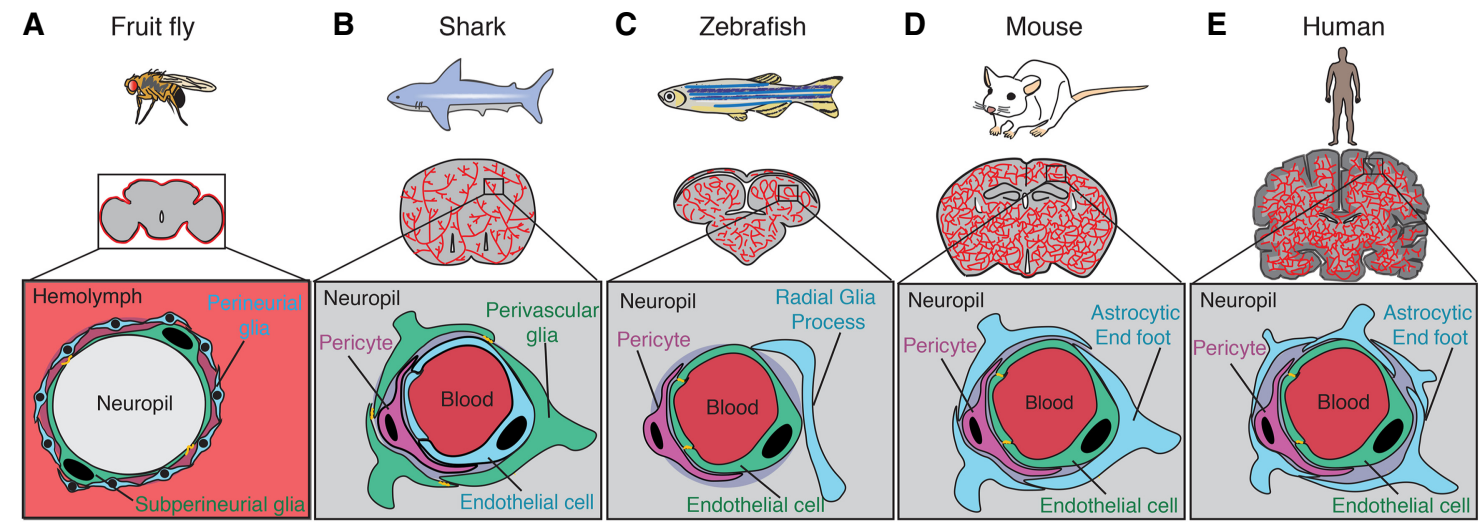

Figure 1. Functional conservation of the barrier across organisms. (A) In fruit flies, the hemolymph-brain barrier partitions the fly neuropil from the hemolymph surrounding the brain, thus performing a function analogous to that of the BBB found in vertebrates. The site of the hemolymph-brain barrier is the SPGs (green), large polyploid cells that enwrap the neural tissue. Subperineurial cells are connected by specialized septate junctions (orange). Perineurial glia (blue) are glial cells that surround the subperineurial layer and also play a role in barrier function. (B) In sharks, the site of the BBB is the perivascular glial cells (green), which are connected by tight junctions (orange) and are found surrounding brain endothelial cells (blue) and pericytes (purple). (C) In zebrafish, the site of the BBB is the capillary endothelial cells (green) that vascularize the brain. These endothelial cells are connected by specialized tight junctions (orange) and are in close contact with brain pericytes (purple). Zebrafish have radial glial cells (blue) that resemble the astrocytes found in mammals; however, their role in the zebrafish BBB has not been well characterized. $(D)$ The site of the mouse BBB is also the capillary endothelial cells (green) that vascularize the brain. As in zebrafish, these cells are connected by specialized tight junctions (orange). BBB endothelial cells together with brain pericytes (purple) and the end feet of astrocytes (blue) comprise the NVU. (E) As in zebrafish and mice, the site of the BBB in humans is also the capillary endothelial cells (green), which are connected by specialized tight junctions (orange). The human NVU also includes pericytes (purple) and astrocytic end feet (blue), which are more prevalent in human brains than in mouse brains.

\section{Endothelial barriers are conserved across vertebrates}

Combinations of these tracer injections and EM analyses have been used to study functional barriers in a variety of organisms, ranging from invertebrates to humans. While the function of the barrier is conserved from organisms such as flies (Limmer et al. 2014) and cartilaginous fish (Bundgaard and Abbott 2008), the cellular nature of the barrier and the NVU required for establishing the barrier varies across taxa.

The fruit fly $D$. melanogaster has an open circulatory system, unlike the closed circulatory system observed in vertebrates; however, the fly brain is separated from the blood-like hemolymph by the so-called "hemolymph-brain barrier" (Fig. 1A; Juang and Carlson 1992; Bainton et al. 2005; Schwabe et al. 2005). This functional barrier is formed by the subperineurial glial cells (SPGs) (Schwabe et al. 2005; Limmer et al. 2014). These glial cells undergo polyploidization during larval stages, greatly increasing their cell area to seal the brain as it develops (Unhavaithaya and Orr-Weaver 2012). SPGs express nutrient transporters and have specialized septate junctions, similar to the expression pattern of nutrient transporters and specialized tight junction complexes in vertebrate BBB endothelial cells (Limmer et al. 2014; Hindle et al. 2017). Interaction with other glial cell types, including perineurial glial cells, has also been shown to be important in regulating size selectivity of the hemolymphbrain barrier through fenestrations (cellular pores) (Stork et al. 2008). Together, these glial cells regulate and re- strict access of the hemolymph into the invertebrate CNS.

Vertebrate brains can grossly be divided into two subtypes based on neuronal complexity. Type 1 brains exhibit minimal neuronal migration away from the ventricular surface and a relatively simple neuronal cytoarchitecture (Butler 2009). Taxa that are classified as type 1 include lampreys, several cartilaginous fish (such as sharks [Fig. 1B] and chimaeras), nonteleost ray-finned fish, lungfish, and amphibians. Type 2 brains, on the other hand, not only have increased their total neuronal abundance and complexity but also display stereotypic neuronal migration away from the ventricular surface during development. Taxa with type 2 brains include hagfish, teleost ray-finned fish, and amniotes (mammals, reptiles, and birds) (Butler 2009). Interestingly, among the type 1 brains, there are two types of barriers between the blood and the brain: endothelial and glial. While the vast majority of these species has an endothelial barrier similar to that observed in all type 2 brains, the elasmobranchii (sharks, skates, and rays) and sturgeon brains are protected by a glial barrier similar to the more primitive hemolymph-brain barrier observed in the invertebrate fly $D$. melanogaster (Bundgaard and Cserr 1981; Bundgaard and Abbott 2008). EM analyses following HRP injection have been performed in species spanning several different taxa, and it appears that the endothelial barrier has evolved several times throughout evolution (Bundgaard and Abbott 2008). The BBB has remained in other vertebrates, likely due to strong selection for diversification 
of brain cell types and functions and thus for more complex neuronal tasks (Abbott 2005).

EM studies have revealed that the endothelial barrier exists in a number of species, including newts (Bodenheimer and Brightman 1968), zebrafish (Fig. 1C; Fleming et al. 2013), chickens and quails (Stewart and Wiley 1981b), opossums (Ek et al. 2006), wallabies (Dziegielewska et al. 1988), mice (Fig. 1D; Reese and Karnovsky 1967), rats (Olsson et al. 1968), rabbits (Sedlakova et al. 1999), cats (Waldron and Bryan 1975; Ellison et al. 1987), dogs (Vick and Bigner 1972), and humans (Fig. 1E; Long 1970; Stewart et al. 1987). Of these, mice are the most commonly used BBB model system (Fig. 1D). However, zebrafish (Fig. 1C) are also emerging as a powerful system to study the barrier. Study of both mouse and zebrafish systems provides a complementary approach to uncover the molecular and cellular regulators of barrier properties.

\section{Comparing the role of BBB cellular constituents in zebrafish and mice}

\section{Endothelial cells}

As detailed above, both zebrafish and mice have an endothelial BBB. Throughout the body, the endothelium serves as a site of transfer for substances between tissues and the blood stream. Thus, endothelial cell properties in different tissues reflect differences in exchange properties (Augustin and Koh 2017; Potente and Mäkinen 2017). For example, in the liver, spleen, and bone marrow, the endothelium is discontinuous, allowing substances to freely pass between the tissue and the blood through gaps between endothelial cells. In the kidneys and endocrine glands, endothelial cells are fenestrated, allowing passage of specific substances through large pores in endothelial cells (Drummond et al. 1998; Satchell and Braet 2009). In most vessels in the body, such as those in the lungs (Schneeberger-Keeley and Karnovsky 1968), endothelial cells are continuous, meaning the cells are attached to one another by cell-cell junctions. Substances pass through continuous endothelium cell-cell junction complexes or via vesicular trafficking across the cell membrane.

Brain endothelial cells are an especially restrictive form of continuous endothelium. They have specialized tight junction complexes that prevent paracellular passage of water-soluble molecules (Nag et al. 2011; Daneman 2012; Andreone et al. 2015). They also express selective transporters to provide nutrients to the brain (CamposBedolla et al. 2014; Zhao et al. 2015). Additionally, CNS endothelial cells express low levels of leukocyte adhesion molecules when compared with peripheral endothelial cells and thus help prevent immune cell entry into the brain (Rössler et al. 1992). Finally, CNS endothelial cells exhibit unusually low levels of vesicular transport (transcytosis), as described above (Reese and Karnovsky 1967). Increased levels of vesicles and BBB leakage have been observed under pathologic conditions, such as ischemia (Lossinsky and Shivers 2004), as well as in mice with decreased pericyte coverage (Armulik et al. 2010; Bell et al. 2010; Daneman et al. 2010b). Recently, work demonstrat- ed that transcytosis is actively inhibited in CNS endothelial cells. Specifically, $M f_{s} d 2 a$, a multitransmembrane lipid transporter (Nguyen et al. 2014), functions as a transcytosis inhibitor to regulate the BBB. Mice lacking Mfsd2a have a leaky $\mathrm{BBB}$ and $\mathrm{BRB}$, resulting from up-regulation of transcytosis without apparent disruption of tight junctions (Ben-Zvi et al. 2014; Chow and Gu 2017). Recent work has established the mechanism of action of Mfsd2a: Lipids translocated by Mfsd2a establish a unique lipid composition in the CNS endothelial cell plasma membrane that inhibits formation of caveolae (Andreone et al. 2017), which are small "flask-shaped" plasma membrane invaginations (Palade 1953; Yamada 1955). Moreover, the suppression of transcytosis is also important for the establishment of a functional barrier during development. In the developing retina, blood vessels are leaky when they first enter the retina, and endothelial cells display a relatively high rate of bulk transcytosis (Chow and Gu 2017). However, the specialized tight junctions are already functional as soon as blood vessels enter the retina. An impermeable barrier is established later only after transcytosis is gradually suppressed in the endothelial cells. Therefore, the time course of transcytosis regulation governs the development of an impermeable functional BRB (Chow and Gu 2017).

Expression of several molecules is conserved between mouse and zebrafish CNS endothelial cells. Briefly, mouse CNS endothelial cells express both general endothelial genes, such as Pecam1, Kdr (Vegfr2), Cldn5, and Tjp1 (ZO-1), and unique or highly enriched genes, such as Slc2a1 (Glut1), $A b c b 1$ (Pgp), Mfsd2a, and Lsr (Daneman et al. 2010a; Ben-Zvi et al. 2014; Zhang et al. 2014). In zebrafish, general endothelial cell markers are also expressed, including the tight junction molecules ZO-1 and Cldn5 (Jeong et al. 2008). Additionally, CNS-enriched genes such as the glucose transporter Glut1 (Umans et al. 2017) and the efflux pump Pgp (Fleming et al. 2013) are also expressed in zebrafish brain endothelial cells. Taken together, the expression of similar molecular BBB regulators in both zebrafish and mice suggests that the brain endothelium in zebrafish plays a role analogous to that of the mouse brain endothelium at the BBB. For a more detailed description of currently known key molecules for BBB function in mouse endothelial cells, see Chow and Gu (2015).

\section{Pericytes}

Pericytes are a subset of mural cells that are in close contact with capillary endothelial cells throughout the body (Armulik et al. 2011). In the mammalian brain, pericytes contact endothelial cells and astrocytic end feet through the basal lamina, forming an integral part of the NVU (Fig. 2; Hawkins 2005; Stanimirovic and Friedman 2012; Najjar et al. 2013). The function and characteristics of pericytes at the BBB in mice have been reviewed extensively (Armulik et al. 2011; Winkler et al. 2011; Sweeney et al. 2016; Trost et al. 2016).

Briefly, these vascular support cells are present at the time of embryonic brain vascularization in rodents and 


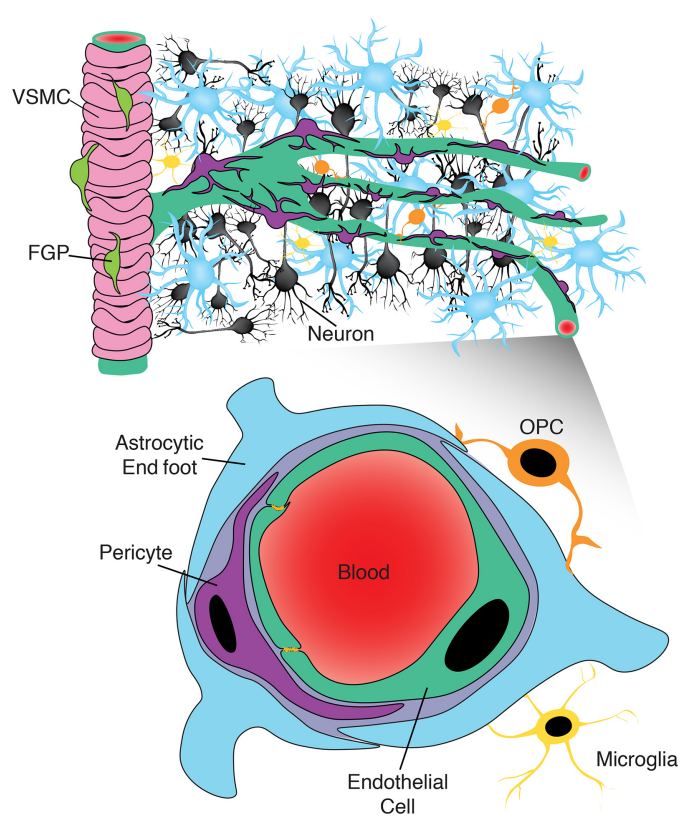

Figure 2. Expanded view of the NVU. While the canonical view of the NVU includes neurons (black), endothelial cells (green), pericytes (purple), and astrocytes (blue), recent evidence suggests that this view may be too limited. Recent work has identified a role for fluorescent granular perithelial cells (FGPs; lime green) in regulating arteriole permeability, marked here by the presence of vascular smooth muscle cells (VSMCs; pink). At the capillary level, there may also be an underappreciated role for cells such as oligodendrocyte precursor cells (OPCs; orange) and microglia (yellow) in regulating the $\mathrm{BBB}$, given their proximity to brain capillaries.

have been shown to be essential for the formation of the BBB (Daneman et al. 2010b). The requirement of pericytes during $\mathrm{BBB}$ formation was demonstrated using several mouse models with genetic alterations that disrupt the interaction of pericytes and brain endothelial cells-socalled "pericyte-deficient" mice. Studies with pericytedeficient mice also revealed that the degree of pericyte coverage along the brain vasculature negatively correlates with barrier permeability (Armulik et al. 2010; Bell et al. 2010; Daneman et al. 2010b). Further investigation of adult $P d g f b^{\text {ret/ret }}$ pericyte-deficient mice revealed regional heterogeneity in barrier permeability, finding higher levels of permeability in the cortex, striatum, and hippocampus than in the interbrain and midbrain despite similar levels of pericyte coverage (Villaseñor et al. 2016). Additional analysis with $P d g r f b^{+/-}$mice showed defects in neurovascular coupling during adulthood (Kisler et al. 2017b). However, a recent study in the mouse retina demonstrated that while pericytes are also necessary for the development of the BRB, loss of pericytes after the formation of the BRB during adulthood has no effect on retinal barrier properties (Park et al. 2017). Similarly, when the investigators analyzed Evans blue leakage in the gross adult brain after acute loss of pericytes, they did not observe increased tracer leakage into the brain, suggesting that pericytes are not necessary for the main- tenance of barrier properties during adulthood (Park et al. 2017).

Recent work suggests that the differentiation state of pericytes may influence their effect on BBB permeability. One study performed in mice deficient for the transcription factor Foxf2, a neural crest-derived mural cell marker, found that $\mathrm{Foxf2}^{-/-}$pericytes had defective differentiation patterns and observed increased pericyte coverage and BBB leakage in both the embryonic brain in germline null animals and the adult brain in conditional null animals (Reyahi et al. 2015). Another recent study in mice found that pericytes are present at the leaky angiogenic front before retinal endothelial cells acquire the BRB, further suggesting that the differentiation state of pericytes is important to promote the acquisition of barrier properties in retinal endothelial cells (Chow and Gu 2017). Finally, recent studies have sought to determine the role of pericytes in the pathology of neurodegenerative diseases (Bell et al. 2010, 2012; Kisler et al. 2017a), finding that pericyte dysfunction typically precedes neurodegeneration in mouse models. Given that some studies suggest that pericyte loss during adulthood is not critical for maintaining barrier properties, further work is needed to clearly evaluate the role of pericytes in the adult $\mathrm{BBB}$, specifically how pericyte differentiation state affects brain endothelial cell barrier properties and whether pericytes are critical for maintaining barrier properties during adulthood.

The close physical interaction between brain pericytes and endothelial cells is not unique to mammals, as zebrafish endothelial cells are also in close contact with pericytes throughout BBB formation. The first CNS Pdgfrb ${ }^{+}$ pericytes appear on the hindbrain channels $\sim 60 \mathrm{~h}$ post-fertilization (hpf) (Wang et al. 2013; Ando et al. 2016). Interestingly, at this age, some pericytes are associated with the angiogenic sprouting front of capillaries penetrating the brain (Wang et al. 2013) even though the barrier is not fully functional, similar to observations in the mammalian retina described above (Chow and Gu 2017). Live imaging in developing zebrafish embryos enables imaging of the brain in toto, a key advantage to using zebrafish for the study of barrier development. Such studies have revealed that pericytes stop migrating and proliferating at $5 \mathrm{dpf}$, after covering the entire cranial vasculature (Ando et al. 2016). While these Pdgfrb $^{+}$pericytes also express Notch3, they do not express other canonical mammalian pericyte markers (e.g., Rgs5a, Desmin a/b, or Cspg4) (Wang et al. 2013), suggesting that there are some molecular differences between mammalian and zebrafish pericytes. Interestingly, using a combination of morpholino gene knockdown and lineage tracing experiments, it has been determined that these zebrafish cranial pericytes are of mixed developmental origin from both the neural crest and mesenchyme (Ando et al. 2016), while, in the mammalian system, these cells are only of neural crest origin (Bergwerff et al. 1998; Etchevers et al. 2001; Korn et al. 2002; Wilm et al. 2005; Que et al. 2008; Asahina et al. 2011; Yamanishi et al. 2012). Thus, while zebrafish pericytes share several features with mouse pericytes, the precise role of pericytes in the zebrafish $\mathrm{BBB}$ is not currently known. 


\section{Astrocytes}

Due to their proximity to CNS endothelial cells, astrocytes have been thought to play a role in BBB function (Fig. 2). Unlike pericytes, astrocytes are unique to the CNS and perform a wide array of processes to maintain proper neuronal function (Kimelberg and Nedergaard 2010). Much work has been done to investigate the effect of astrocyte-secreted factors using in vitro BBB endothelial cell models with mouse or human cells (Haseloff et al. 2005; Abbott et al. 2006). However, gliogenesis occurs after functional BBB formation during embryonic development in mice (Kwan et al. 2012), excluding their possible role in the establishment of the BBB in vivo. In adults, astrocytes interact with brain endothelial cells through their end feet (Abbott et al. 2006), which suggests that they are likely to be involved in the maintenance of BBB endothelial cell properties. To date, the role of astrocytes in the BBB has been implicated mostly through astrocyte dysfunction in the pathogenesis of several neurodegenerative diseases where it is known that BBB function is compromised (Abbott et al. 2006; Carvey et al. 2009; Daneman 2012; Obermeier et al. 2013; Phatnani and Maniatis 2015). However, whether astrocyte dysfunction contributes to or results from compromised BBB function during neurodegenerative disease is not yet clear. Nonetheless, as much of our understanding of astrocyte regulation of the BBB has been gained from disease models in which BBB function is compromised, more research is needed to better understand how astrocytes regulate BBB function under normal physiological conditions.

While the in vivo role of astrocytes in the BBB is not yet known, several studies from rodents indicate that astrocytes selectively regulate BBB permeability. For example, studies where adult rat brain astrocytes were transplanted into rat iris tissue indicated that the presence of astrocytes is sufficient to confer barrier function to endothelial cells that vascularized the astrocytic grafts (Janzer and Raff 1987). Additionally, other studies have indicated that astrocytes restrict immune access into the brain. For example, one study implicated Hedgehog pathway signaling between astrocytes and brain endothelial cells in regulating immune cell entry into the brain (Alvarez et al. 2011), while another found that Vegfa secretion in astrocytes increased immune infiltration into the brain in a multiple sclerosis mouse model (Argaw et al. 2012).

In mice, astrocytes are identified by their expression of several markers, including the intermediate filament Gfap, the water channel Aqp4, and the enzyme Aldh111 (Zhang et al. 2014). While zebrafish do not possess the classic stellate astrocytes, they do contain a population of radial glia, which express several key astrocytic molecular markers. However, whether these astrocyte-like cells play a role in BBB function remains unclear. Zebrafish radial glia express Gfap in long extending processes (Jeong et al. 2008) and react to CNS (retina and spinal cord) damage in ways similar to those of reactive astrocytes in mice (Neve et al. 2012). While zebrafish radial glia also express glutamine synthetase (GS), Aqp4 (Grupp et al. 2010), and several tight junction markers, as seen in mouse as- trocytic end feet (Corbo et al. 2012), these markers do not necessarily share the same cellular distribution as mammalian astrocytes. For example, in mammals, Aqp4 is highly polarized in astrocytic end feet in direct contact with blood vessels, but, in zebrafish, Aqp4 is localized throughout entire radial glial processes, indicating a lack of polarization, and Aqp4 ${ }^{+}$radial glial processes rarely contact the vasculature (Grupp et al. 2010). Similarly, Gfap ${ }^{+}$radial glia rarely appear in close proximity to blood vessels. Taken together, these observations suggest that while radial glia may play several key roles for ion homeostasis in zebrafish brains, their role in the BBB may not be the same as that of astrocytes in mammals. This differential role for radial glia in the zebrafish BBB may be related to their evolutionary standing, as zebrafish have a more ancestral endothelial BBB than mammals, with a less complex NVU, and this should be remembered when using zebrafish as a model system to draw larger comparisons with human barrier physiology.

\section{Other cell types}

Pericytes and astrocytes are considered the key cell types involved in $\mathrm{BBB}$ regulation through their interactions with brain endothelial cells. However, several other cell types, including fluorescent granular perithelial cells (FGPs), oligodendrocyte precursor cells (OPCs), and microglia (Fig. 2), also lie in close proximity to CNS blood vessels. Recent work has suggested that these other cell types may regulate $\mathrm{BBB}$ permeability, arguing for an expansion of the classical view of the NVU.

For example, FGPs are a class of brain cells that are found along the meningeal vasculature and in the perivascular space lining brain arteries. They were discovered in rats (Mato et al. 1981) and recently were also characterized in zebrafish (Bower et al. 2017; Venero Galanternik et al. 2017). These cells_known as FGPs (Mato et al. 1981; Venero Galanternik et al. 2017), perivascular microglial (PVM) cells (Hickey and Kimura 1988), ED2-positive perivascular cells (Graeber et al. 1989), or mural lymphatic endothelial cells (Bower et al. 2017)-have been implicated in regulating barrier properties and maintaining CNS homeostasis (Mato et al. 1996; Jais et al. 2016; Bower et al. 2017; Venero Galanternik et al. 2017). Lineage tracing studies in zebrafish demonstrate that these cell types are derived from the optic choroidal vascular plexus endothelium (a blood vessel). Cells sprout from this structure and then migrate to the pial surface to form a lymphatic endothelium (lymphatic vessels) that comprises the lymphatic loop. From this stage, these cells spread over the brain surface, associating next to the blood vessels and adopting a morphology characteristic of macrophages, becoming the so-called "mural lymphatic endothelial cells" (Bower et al. 2017; Venero Galanternik et al. 2017). However, studies performed in rats using irradiation followed by bone marrow transplantation indicated that these cells are bone marrow-derived (Hickey and Kimura 1988). Further work is needed to determine whether there are species-specific differences in the origin of these cells or 
whether the embryonic and adult forms of these cells are derived from different cellular pools.

Additionally, a recent study found a role for OPCs in BBB permeability in mice (Seo et al. 2014). This work provided evidence that OPCs contact BBB endothelial cells in the mouse brain. Additionally, cerebral hemorrhage was observed in a dose-dependent manner in adult mouse brains when Pdgfra-Cre was used to knock out Tgfb1 expression in OPCs, indicating that Tgfbl signaling from OPCs regulates barrier permeability. A second localization study provided further evidence that OPCs physically interact with the pericytes of the BBB NVU (Maki et al. 2015). However, elucidating the role of OPCs in BBB maintenance and determining whether these cells influence BBB permeability in zebrafish require further study.

Finally, microglia are present in the brain during the time of BBB development in humans, mice, and zebrafish (Hutchins et al. 1990; Herbomel et al. 1999, 2001; Ginhoux et al. 2010; Schulz et al. 2012). They play a role in brain angiogenesis and CNS vascularization during development in mice and zebrafish (Fantin et al. 2010; Rymo et al. 2011) and are found perivascularly in the adult brain (Dudvarski Stankovic et al. 2016). Interestingly, recent work suggests that microglia may play an integral role in BBB repair after brain vascular injury (Lou et al. 2016). However, their role in BBB development and maintenance has been largely unexplored.

Much work has been done to profile the molecular signatures of each BBB cell type by microarray or RNA sequencing (Bondjers et al. 2006; Armulik et al. 2010; Daneman et al. 2010a; Ben-Zvi et al. 2014; Zhang et al. 2014; He et al. 2016). Some of these transcriptional studies have begun to reveal commonalities and differences not only between cell types within species but also within cell types between species (Zhang et al. 2014; Bennett et al. 2016). Comparative proteomics have also revealed that rodent and primate brain endothelial cells have similar proteomes but that levels of specific proteins (notably several transporters, including the multidrug resistance transporter p-glycoprotein) may vary across species (Uchida et al. 2011; Hoshi et al. 2013). Thus, the differences between animal models and humans should be taken into consideration when translating research findings observed in model organisms to therapeutic strategies in humans. Furthermore, with the advent of new sequencing technologies, single-cell sequencing provides an opportunity to further characterize the cellular roles of all NVU components in the BBB using an unbiased approach. Recent single-cell data suggest that there are nuanced differences within these general cell populations and provide a new opportunity to discover novel cellular players at the BBB (Darmanis et al. 2015; Zeisel et al. 2015).

\section{From model organism to the human BBB}

While it has been established by EM that humans have an endothelial BBB with structural similarities to those found in model organisms, such as tight junction complexes between endothelial cells, low levels of transcytosis within endothelial cells, and close contact with pericytes and astrocytes (Allsopp and Gamble 1979), the precise functional properties of the human barrier remain elusive, as it is challenging to perform the standard BBB assays in humans. However, several studies performed in humans provide hints as to how the human BBB may form and function. Importantly, Grontoft (1954) performed trypan blue leakage assays in aborted human fetuses and demonstrated that, as in mice and zebrafish, the functional human BBB is acquired during embryonic development.

Several studies have sought to assess leakage in human disease states using endogenous plasma protein leakage in post-mortem human tissue. Using immunostaining against endogenous serum proteins, such as fibrinogen and IgG as in mice, several groups have seen an increase in barrier permeability, as evidenced by an increased number of perivascular cells with positive staining associated with disease states such as malaria (Brown et al. 1999) and Alzheimer's disease (Ryu and McLarnon 2009). While these studies observed plasma protein staining in both aged and diseased brain states, with stronger leakage observed in diseased brains, an additional study by Bridges et al. (2014) found that leakage of fibrinogen and IgG is a general feature of aged brains rather than being specifically associated with disease.

Recently, a study performed with DCE-MRI in human patients with mild cognitive impairment helped to clarify these findings. This work demonstrated that study participants showed an age-dependent increase in BBB leakage only in the hippocampus that was accelerated by the onset of mild cognitive impairment, a disease state associated with early stage Alzheimer's disease (Montagne et al. 2015). The investigators supported their MRI findings by measuring increased levels of albumin in the CSF of patients with mild cognitive impairment. They further correlated this increased $\mathrm{BBB}$ leakage and the associated cognitive dysfunction with markers of pericyte damage in the CSF, suggesting that age-dependent BBB leakage could cause pericyte dysfunction, which could further promote the increased BBB leakage observed in $\mathrm{Alz}$ heimer's disease brains. Taken together, these studies suggest that the human brain likely exhibits increased BBB leakage with age. However, further work is needed to clarify regional leakage patterns and determine the permeability of specific endogenous leakage substrates in both normal and disease states.

From tracer assays of BBB function, analyses of BBB evolutionary conservation, and dissection of NVU cell type functions, we are beginning to uncover how the BBB functions in model organisms. However, there is a relative dearth of information directly analyzing these features and functions in the human BBB. While human brains are relatively similar to those of other mammals and fish, human brains have several species-specific adaptations. Whether these differences in brain composition and cellular subtypes alter BBB properties remains to be seen. For example, human brains are known to have a higher proportion and increased complexity of neocortical astrocytes than rodent brains (Oberheim et al. 2006). As astrocytes are a central component of the NVU, it will be 
important to determine whether the higher astrocyte to neuron ratio affects $\mathrm{BBB}$ properties in human brains. In addition to the increased astrocytic abundance, humans have also expanded their neurogenic proliferative zone beyond the ventricular zone and subventricular zone to include a totally unique stem cell niche in the outer subventricular zone (Lui et al. 2011), and how these differences in neurogenesis might affect BBB properties remains to be seen.

Recent work has sought to use human induced pluripotent stem cells (iPSCs) (Lippmann et al. 2014; Lim et al. 2017; Vatine et al. 2017) to model human BBB function in vitro. Use of such in vitro systems has the potential to provide insight into how genetic alterations that lead to neurological diseases may affect brain endothelial cell properties, especially in diseases where mouse models fail to recapitulate critical disease phenotypes. For example, a recent study generated iPSCs from human patients with MCT8 deficiency (Vatine et al. 2017). Patients with this genetic mutation have altered thyroid hormone levels and exhibit severe neuropsychomotor impairments. Mouse models mimic some aspects of this disease but fail to display key neurological phenotypes after alteration of S1c16a2 (the gene encoding Mct8) alone because mouse brain endothelial cells express high levels of another thyroid transporter that is not expressed in human brain endothelial cells. Use of patient-derived iPSCs that were differentiated to brain endothelial cells permitted molecular characterization of how SLC16A2 mutation likely affects MCT8-mediated thyroid transport into the brain in this disease (Vatine et al. 2017). Thus, work using such human in vitro systems together with comparative BBB studies on differences in BBB composition and function across species can elucidate how the human BBB functions. Due to limited samples and information on the human BBB, it is crucial to use a multipronged approach when studying the BBB. While research performed with model organisms, in vitro human cell culture, and MRI-DCE imaging in humans each has strengths and weaknesses, together they are complementary approaches for testing hypotheses about how the human barrier may be regulated in order to guide therapeutic avenues.

\section{Conclusion}

While we have made much progress during the last century in defining barrier properties and characterizing the cellular nature of the $\mathrm{BBB}$, the molecular underpinnings of these properties require further examination. We are just beginning to understand how BBB properties are established in brain endothelial cells on a molecular level. While the developmental acquisition of BBB properties has been characterized, future work aims to also elucidate how BBB properties are maintained during adulthood both under normal physiological conditions and in disease states. In addition to studying brain endothelial cells and pericytes, how other cell types comprising the NVU regulate BBB properties should also be investigated in vivo. Finally, the nature and properties of the human $\mathrm{BBB}$ remain largely unknown. With future technological advances and ongoing comparative studies, better understanding of the human BBB can be gained to improve therapeutic efficacy for clinical treatment of brain malignancies and neurodegenerative diseases.

\section{Acknowledgments}

We thank members of the Gu laboratory for critical reading of this manuscript. This work was supported by the National Institutes of Health DP1 NS092473 Pioneer Award to C.G., N.M.O. and S.J.P. were supported by Damon Runyon Post-doctoral Fellowships. The research of C.G. was also supported in part by a Faculty Scholar grant from the Howard Hughes Medical Institute.

\section{References}

Abbott NJ. 2005. Dynamics of CNS barriers: evolution, differentiation, and modulation. Cell Mol Neurobiol 25: 5-23.

Abbott NJ, Rönnbäck L, Hansson E. 2006. Astrocyte-endothelial interactions at the blood-brain barrier. Nat Rev Neurosci 7: 41-53.

Adams RA, Bauer J, Flick MJ, Sikorski SL, Nuriel T, Lassmann H, Degen JL, Akassoglou K. 2007. The fibrin-derived $\gamma$ 377-395 peptide inhibits microglia activation and suppresses relapsing paralysis in central nervous system autoimmune disease. $I$ Exp Med 204: 571-582.

Allsopp G, Gamble HJ. 1979. Light and electron microscopic observations on the development of the blood vascular system of the human brain. J Anat 128: 461-477.

Alvarez JI, Dodelet-Devillers A, Kebir H, Ifergan I, Fabre PJ, Terouz S, Sabbagh M, Wosik K, Bourbonnière L, Bernard M, et al. 2011. The Hedgehog pathway promotes blood-brain barrier integrity and CNS immune quiescence. Science 334: 1727-1731.

Ando K, Fukuhara S, Izumi N, Nakajima H, Fukui H, Kelsh RN, Mochizuki N. 2016. Clarification of mural cell coverage of vascular endothelial cells by live imaging of zebrafish. Development 143: 1328-1339.

Andreone BJ, Lacoste B, Gu C. 2015. Neuronal and vascular interactions. Annu Rev Neurosci 38: 25-46.

Andreone BJ, Chow BW, Tata A, Lacoste B, Ben-Zvi A, Bullock K, Deik AA, Ginty DD, Clish CB, Gu C. 2017. Blood-brain barrier permeability is regulated by lipid transport-dependent suppression of caveolae-mediated transcytosis. Neuron $\mathbf{9 4}$ : 581-594.e5.

Argaw AT, Asp L, Zhang J, Navrazhina K, Pham T, Mariani JN, Mahase S, Dutta DJ, Seto J, Kramer EG, et al. 2012. Astrocyte-derived VEGF-A drives blood-brain barrier disruption in CNS inflammatory disease. J Clin Invest 122: 2454-2468.

Armulik A, Genové G, Mäe M, Nisancioglu MH, Wallgard E, Niaudet C, He L, Norlin J, Lindblom P, Strittmatter K, et al. 2010. Pericytes regulate the blood-brain barrier. Nature 468: 557-561.

Armulik A, Genové G, Betsholtz C. 2011. Pericytes: developmental, physiological, and pathological perspectives, problems, and promises. Dev Cell 21: 193-215.

Asahina K, Zhou B, Pu WT, Tsukamoto H. 2011. Septum transversum-derived mesothelium gives rise to hepatic stellate cells and perivascular mesenchymal cells in developing mouse liver. Hepatology 53: 983-995.

Augustin HG, Koh GY. 2017. Organotypic vasculature: from descriptive heterogeneity to functional pathophysiology. Science 269: eaal2379. 
Bainton RJ, Tsai LT-Y, Schwabe T, DeSalvo M, Gaul U, Heberlein U. 2005. moody encodes two GPCRs that regulate cocaine behaviors and blood-brain barrier permeability in Drosophila. Cell 123: 145-156.

Bell RD, Winkler EA, Sagare AP, Singh I, LaRue B, Deane R, Zlokovic BV. 2010. Pericytes control key neurovascular functions and neuronal phenotype in the adult brain and during brain aging. Neuron 68: 409-427.

Bell RD, Winkler EA, Singh I, Sagare AP, Deane R, Wu Z, Holtzman DM, Betsholtz C, Armulik A, Sallstrom J, et al. 2012. Apolipoprotein E controls cerebrovascular integrity via cyclophilin A. Nature 485: 512-516.

Bennett ML, Bennett FC, Liddelow SA, Ajami B, Zamanian JL, Fernhoff NB, Mulinyawe SB, Bohlen CJ, Adil A, Tucker A, et al. 2016. New tools for studying microglia in the mouse and human CNS. Proc Natl Acad Sci 113: E1738-E1746.

Ben-Zvi A, Lacoste B, Kur E, Andreone BJ, Mayshar Y, Yan H, Gu C. 2014. Mfsd2a is critical for the formation and function of the blood-brain barrier. Nature 509: 507-511.

Bergwerff M, Verberne ME, DeRuiter MC, Poelmann RE, Gittenberger-de Groot AC. 1998. Neural crest cell contribution to the developing circulatory system: implications for vascular morphology? Circ Res 82: 221-231.

Bodenheimer TS, Brightman MW. 1968. A blood-brain barrier to peroxidase in capillaries surrounded by perivascular spaces. Am I Anat 122: 249-267.

Bondjers C, He L, Takemoto M, Norlin J, Asker N, Hellstrom M, Lindahl P, Betsholtz C. 2006. Microarray analysis of blood microvessels from PDGF-B and PDGF-Rb tifies novel markers for brain pericytes. FASEB J 20: 1703-1705.

Bower NI, Koltowska K, Pichol-Thievend C, Virshup I, Paterson S, Lagendijk AK, Wang W, Lindsey BW, Bent SJ, Baek S, et al. 2017. Mural lymphatic endothelial cells regulate meningeal angiogenesis in the zebrafish. Nat Neurosci 20: 774-783.

Bridges LR, Andoh J, Lawrence AJ, Khoong CHL, Poon WW, Esiri MM, Markus HS, Hainsworth AH. 2014. Blood-brain barrier dysfunction and cerebral small vessel disease (arteriolosclerosis) in brains of older people. I Neuropathol Exp Neurol 73: 1026-1033.

Brightman MW, Reese TS. 1969. Junctions between intimately apposed cell membranes in the vertebrate brain. I Cell Biol 40: 648-677.

Brown H, Hien TT, Day N, Mai NT, Chuong LV, Chau TT, Loc PP, Phu NH, Bethell D, Farrar J, et al. 1999. Evidence of blood-brain barrier dysfunction in human cerebral malaria. Neuropathol Appl Neurobiol 25: 331-340.

Bundgaard M, Abbott NJ. 2008. All vertebrates started out with a glial blood-brain barrier 4-500 million years ago. Glia 56: 699-708.

Bundgaard M, Cserr H. 1981. A glial blood-brain barrier in elasmobranchs. Brain Res 226: 61-73.

Butler AB. 2009. Evolution of vertebrate brains. In Encyclopedia of neuroscience, Vol. 4 (ed. Squire LR), pp. 57-66. Academic Press, New York.

Campos-Bedolla P, Walter FR, Veszelka S, Deli MA. 2014. Role of the blood-brain barrier in the nutrition of the central nervous system. Arch Med Res 45: 610-638.

Carvey PM, Hendey B, Monahan AJ. 2009. The blood-brain barrier in neurodegenerative disease: a rhetorical perspective. $I$ Neurochem 111: 291-314.

Cho C, Smallwood PM, Nathans J. 2017. Reck and Gpr124 are essential receptor cofactors for Wnt7a/Wnt7b-specific signaling in mammalian CNS angiogenesis and blood-brain barrier regulation. Neuron 95: 1056-1073.e5.
Chow BW, Gu C. 2015. The molecular constituents of the bloodbrain barrier. Trends Neurosci 38: 598-608.

Chow BW, Gu C. 2017. Gradual suppression of transcytosis governs functional blood-retinal barrier formation. Neuron 93: 1325-1333.e3.

Corbo CP, Othman NA, Gutkin MC, Alonso ADC, Fulop ZL. 2012. Use of different morphological techniques to analyze the cellular composition of the adult zebrafish optic tectum. Microsc Res Tech 75: 325-333.

Cramer SP, Modvig S, Simonsen HJ, Frederiksen JL, Larsson HBW. 2015. Permeability of the blood-brain barrier predicts conversion from optic neuritis to multiple sclerosis. Brain 138: $2571-2583$.

Daneman R. 2012. The blood-brain barrier in health and disease. Ann Neurol 72: 648-672.

Daneman R, Zhou L, Agalliu D, Cahoy JD, Kaushal A, Barres BA. 2010a. The mouse blood-brain barrier transcriptome: a new resource for understanding the development and function of brain endothelial cells. PLOS ONE 5: e13741.

Daneman R, Zhou L, Kebede AA, Barres BA. 2010b. Pericytes are required for blood-brain barrier integrity during embryogenesis. Nature 468: 562-566.

Darmanis S, Sloan SA, Zhang Y, Enge M, Caneda C, Shuer LM, Hayden Gephart MG, Barres BA, Quake SR. 2015. A survey of human brain transcriptome diversity at the single cell level. Proc Natl Acad Sci 112: 7285-7290.

Drummond IA, Majumdar A, Hentschel H, Elger M, Solnica-Krezel L, Schier AF, Neuhauss SC, Stemple DL, Zwartkruis F, Rangini Z, et al. 1998. Early development of the zebrafish pronephros and analysis of mutations affecting pronephric function. Development 125: 4655-4667.

Dudvarski Stankovic N, Teodorczyk M, Ploen R, Zipp F, Schmidt MH. 2016. Microglia-blood vessel interactions: a doubleedged sword in brain pathologies. Acta Neuropathol 131: 347-363.

Dziegielewska KM, Hinds LA, Møllgård K, Reynolds ML, Saunders NR. 1988. Blood-brain, blood-cerebrospinal fluid and cerebrospinal fluid-brain barriers in a marsupial (Macropus eugenii) during development. I Physiol 403: 367-388.

Ehrlich P. 1885. Das sauerstuf-budurfnis des organismus. Eine farbenanalytische studie. Hirschwald, Berlin.

Ek CJ, Dziegielewska KM, Stolp H, Saunders NR. 2006. Functional effectiveness of the blood-brain barrier to small water-soluble molecules in developing and adult opossum (Monodelphis domestica). J Comp Neurol 496: 13-26.

Ellison MD, Povlishock JT, Merchant RE. 1987. Blood-brain barrier dysfunction in cats following recombinant interleukin-2 infusion. Cancer Res 4: 5768-5770.

Etchevers HC, Vincent C, Le Douarin NM, Couly GF. 2001. The cephalic neural crest provides pericytes and smooth muscle cells to all blood vessels of the face and forebrain. Development 128: 1059-1068.

Fantin A, Vieira JM, Gestri G, Denti L, Schwarz Q, Prykhozhij S, Peri F, Wilson SW, Ruhrberg C. 2010. Tissue macrophages act as cellular chaperones for vascular anastomosis downstream of VEGF-mediated endothelial tip cell induction. Blood 116: 829-840.

Fleming A, Diekmann H, Goldsmith P. 2013. Functional characterisation of the maturation of the blood-brain barrier in larval zebrafish. PLOS ONE 8: e77548.

Gaitán MI, Shea CD, Evangelou IE, Stone RD, Fenton KM, Bielekova B, Massacesi L, Reich DS. 2011. Evolution of the bloodbrain barrier in newly forming multiple sclerosis lesions. Ann Neurol 70: 22-29. 
Ginhoux F, Greter M, Leboeuf M, Nandi S, See P, Gokhan S, Mehler MF, Conway SJ, Ng LG, Stanley ER, et al. 2010. Fate mapping analysis reveals that adult microglia derive from primitive macrophages. Science 330: 841-845.

Goldmann EE. 1909. Die aussere und innere sekretion des gesunden und kranken organismus im lichte der 'vitalen farbund'. Beitr Klin Chir 64: 192-265.

Goldmann EE. 1913. Vitalfarbungen am zentralnervensystem. beitrag zur physio-pathologies des plexus chorioideus und der hirnhaute. Abh Preuss Akad Wiss Physik -Math 1: 1-60.

Graeber MB, Streit WJ, Kreutzberg GW. 1989. Identity of ED2positive perivascular cells in rat brain. I Neurosci Res 22: 103-106.

Gray EG. 1961. Ultra-structure of synapses of cerebral cortex and of certain specializations of neuroglial membranes. In Electron Microscopy in Anatomy (ed. Boyd JD, et al.), pp. 54-66. Edward Arnold and Co., London, UK.

Grontoft O. 1954. Intracranial haemorrhage and blood-brain barrier problems in the newborn; a pathologico-anatomical and experimental investigation. Acta Pathol Microbiol Scand Supp1 100: 8-109.

Grupp L, Wolburg H, Mack AF. 2010. Astroglial structures in the zebrafish brain. J Comp Neurol 518: 4277-4287.

Haseloff RF, Blasig IE, Bauer HC, Bauer H. 2005. In search of the astrocytic factor(s) modulating blood-brain barrier functions in brain capillary endothelial cells in vitro. Cell Mol Neurobiol 25: 25-39.

Hawkins BT. 2005. The blood-brain barrier/neurovascular unit in health and disease. Pharmacol Rev 57: 173-185.

He L, Vanlandewijck M, Raschperger E, Andaloussi Mäe M, Jung B, Lebouvier T, Ando K, Hofmann J, Keller A, Betsholtz C. 2016. Analysis of the brain mural cell transcriptome. Sci Rep 6: 35108.

Herbomel P, Thisse B, Thisse C. 1999. Ontogeny and behaviour of early macrophages in the zebrafish embryo. Development 126: $3735-3745$.

Herbomel P, Thisse B, Thisse C. 2001. Zebrafish early macrophages colonize cephalic mesenchyme and developing brain, retina, and epidermis through a M-CSF receptor-dependent invasive process. Dev Biol 238: 274-288.

Hickey WF, Kimura H. 1988. Perivascular microglial cells of the CNS are bone marrow-derived and present antigen in vivo. Science 239: 290-292.

Hindle SJ, Munji RN, Dolghih E, Gaskins G, Orng S, Ishimoto H, Soung A, DeSalvo M, Kitamoto T, Keiser MJ, et al. 2017. Evolutionarily conserved roles for blood-brain barrier xenobiotic transporters in endogenous steroid partitioning and behavior. Cell Rep 21: 1304-1316.

Hoshi Y, Uchida Y, Tachikawa M, Inoue T, Ohtsuki S, Terasaki T. 2013. Quantitative atlas of blood-brain barrier transporters, receptors, and tight junction proteins in rats and common marmoset. J Pharm Sci 102: 3343-3355.

Hutchins KD, Dickson DW, Rashbaum WK, Lyman WD. 1990. Localization of morphologically distinct microglial populations in the developing human fetal brain: implications for ontogeny. Brain Res Dev Brain Res 55: 95-102.

Iadecola C. 2017. The neurovascular unit coming of age: a journey through neurovascular coupling in health and disease. Neuron 96: $17-42$.

Ingrisch M, Sourbron S, Morhard D, Ertl-Wagner B, Kümpfel T, Hohlfeld R, Reiser M, Glaser C. 2012. Quantification of perfusion and permeability in multiple sclerosis: dynamic contrastenhanced MRI in 3D at 3T. Invest Radiol 47: 252-258.

Jais A, Solas M, Backes H, Chaurasia B, Kleinridders A, Theurich S, Mauer J, Steculorum SM, Hampel B, Goldau J, et al. 2016.
Myeloid-cell-derived VEGF maintains brain glucose uptake and limits cognitive impairment in obesity. Cell 165: 882-895

Janzer RC, Raff MC. 1987. Astrocytes induce blood-brain barrier properties in endothelial cells. Nature 325: 253-257.

Jeong J-Y, Kwon H-B, Ahn J-C, Kang D, Kwon S-H, Park JA, Kim K-W. 2008. Functional and developmental analysis of the blood-brain barrier in zebrafish. Brain Res Bull 75: 619-628.

Juang JL, Carlson SD. 1992. Fine structure and blood-brain barrier properties of the central nervous system of a dipteran larva. $J$ Comp Neurol 324: 343-352.

Karnovsky MJ. 1967. The ultrastructural basis of capillary permeability studied with peroxidase as a tracer. I Cell Biol 35: 213-236.

Kimelberg HK, Nedergaard M. 2010. Functions of astrocytes and their potential as therapeutic targets. Neurotherapeutics 7: 338-353.

Kisler K, Nelson AR, Montagne A, Zlokovic BV. 2017a. Cerebral blood flow regulation and neurovascular dysfunction in $\mathrm{Alz}$ heimer disease. Nat Rev Neurosci 18: 419-434.

Kisler K, Nelson AR, Rege SV, Ramanathan A, Wang Y, Ahuja A, Lazic D, Tsai PS, Zhao Z, Zhou Y, et al. 2017b. Pericyte degeneration leads to neurovascular uncoupling and limits oxygen supply to brain. Nat Neurosci 20: 406-416.

Knowland D, Arac A, Sekiguchi KJ, Hsu M, Lutz SE, Perrino J, Steinberg GK, Barres BA, Nimmerjahn A, Agalliu D. 2014. Stepwise recruitment of transcellular and paracellular pathways underlies blood-brain barrier breakdown in stroke. Neuron 82: 603-617.

Korn J, Christ B, Kurz H. 2002. Neuroectodermal origin of brain pericytes and vascular smooth muscle cells. I Comp Neurol 442: 78-88.

Kwan KY, Sestan N, Anton ES. 2012. Transcriptional co-regulation of neuronal migration and laminar identity in the neocortex. Development 139: 1535-1546.

Lewandowsky M. 1900. Zur lehre der cerebrospinal flussigkeit. $Z$ Klinische Medizin 40: 480-494.

Li W, Long JA, Watts LT, Jiang Z, Shen Q, Li Y, Duong TQ. 2014. A quantitative MRI method for imaging blood-brain barrier leakage in experimental traumatic brain injury. PLOS ONE 9: e114173.

Lim RG, Quan C, Reyes-Ortiz AM, Lutz SE, Kedaigle AJ, Gipson TA, Wu J, Vatine GD, Stocksdale J, Casale MS, et al. 2017. Huntington's disease iPSC-derived brain microvascular endothelial cells reveal WNT-mediated angiogenic and bloodbrain barrier deficits. Cell Rep 19: 1365-1377.

Limmer S, Weiler A, Volkenhoff A, Babatz F, Klämbt C. 2014. The Drosophila blood-brain barrier: development and function of a glial endothelium. Front Neurosci 8: 365.

Lippmann ES, Al-Ahmad A, Azarin SM, Palecek SP, Shusta EV. 2014. A retinoic acid-enhanced, multicellular human bloodbrain barrier model derived from stem cell sources. Sci Rep 4: 4160 .

Liu X, Ide JL, Norton I, Marchionni MA, Ebling MC, Wang LY, Davis E, Sauvageot CM, Kesari S, Kellersberger KA, et al. 2013. Molecular imaging of drug transit through the bloodbrain barrier with MALDI mass spectrometry imaging. Sci Rep 3: 2859.

Long DM. 1970. Capillary ultrastructure and the blood-brain barrier in human malignant brain tumors. I Neurosurg 32: 127-144.

Lossinsky AS, Shivers RR. 2004. Structural pathways for macromolecular and cellular transport across the blood-brain barrier during inflammatory conditions. Review. Histol Histopathol 19: $535-564$. 
Lou N, Takano T, Pei Y, Xavier AL, Goldman SA, Nedergaard M. 2016. Purinergic receptor P2RY12-dependent microglial closure of the injured blood-brain barrier. Proc Natl Acad Sci 113: 1074-1079.

Lui JH, Hansen DV, Kriegstein AR. 2011. Development and evolution of the human neocortex. Cell 146: 18-36.

Maki T, Maeda M, Uemura M, Lo EK, Terasaki Y, Liang AC, Shindo A, Choi YK, Taguchi A, Matsuyama T, et al. 2015. Potential interactions between pericytes and oligodendrocyte precursor cells in perivascular regions of cerebral white matter. Neurosci Lett 597: 164-169.

Mato M, Ookawara S, Aikawa E, Kawasaki K. 1981. Studies on fluorescent granular perithelium (F.G.P.) of rat cerebral cortex - especially referring to morphological changes in aging. Anatomischer Anzeiger 149: 486-501.

Mato M, Ookawara S, Sakamoto A, Aikawa E, Ogawa T, Mitsuhashi U, Masuzawa T, Suzuki H, Honda M, Yazaki Y, et al. 1996. Involvement of specific macrophage-lineage cells surrounding arterioles in barrier and scavenger function in brain cortex. Proc Natl Acad Sci 93: 3269-3274.

Mazzoni J, Smith JR, Shahriar S, Cutforth T, Ceja B, Agalliu D. 2017. The Wnt inhibitor Apcdd1 coordinates vascular remodeling and barrier maturation of retinal blood vessels. Neuron 96: 1055-1069.e6.

Montagne A, Barnes SR, Sweeney MD, Halliday MR, Sagare AP, Zhao Z, Toga AW, Jacobs RE, Liu CY, Amezcua L, et al. 2015. Blood-brain barrier breakdown in the aging human hippocampus. Neuron 85: 296-302.

Montagne A, Zhao Z, Zlokovic BV. 2017. Alzheimer's disease: a matter of blood-brain barrier dysfunction? I Exp Med 214: 3151-3169.

Nag S, Kapadia A, Stewart DJ. 2011. Review: molecular pathogenesis of blood-brain barrier breakdown in acute brain injury. Neuropathol Appl Neurobiol 37: 3-23.

Najjar S, Pearlman DM, Alper K, Najjar A, Devinsky O. 2013. Neuroinflammation and psychiatric illness. I Neuroinflammation 10: 43.

Navarathna DHMLP, Munasinghe J, Lizak MJ, Nayak D, McGavern DB, Roberts DD. 2013. MRI confirms loss of blood-brain barrier integrity in a mouse model of disseminated candidiasis. NMR Biomed 26: 1125-1134.

Neve LD, Savage AA, Koke JR, Garcia DM. 2012. Activating transcription factor 3 and reactive astrocytes following optic nerve injury in zebrafish. Comp Biochem Physiol C Toxicol Pharmacol 155: 213-218.

Nguyen LN, Ma D, Shui G, Wong P, Cazenave-Gassiot A, Zhang X, Wenk MR, Goh ELK, Silver DL. 2014. Mfsd2a is a transporter for the essential omega-3 fatty acid docosahexaenoic acid. Nature 509: 503-506.

Nitta T, Hata M, Gotoh S, Seo Y, Sasaki H, Hashimoto N, Furuse M, Tsukita S. 2003. Size-selective loosening of the bloodbrain barrier in claudin-5-deficient mice. I Cell Biol 161: 653-660.

Oberheim NA, Wang X, Goldman S, Nedergaard M. 2006. Astrocytic complexity distinguishes the human brain. Trends Neurosci 29: 547-553.

Obermeier B, Daneman R, Ransohoff RM. 2013. Development, maintenance and disruption of the blood-brain barrier. Nat Med 19: 1584-1596.

Olsson Y, Klatzo I, Sourander P, Steinwall O. 1968. Blood-brain barrier to albumin in embryonic new born and adult rats. Acta Neuropathol 10: 117-122.

Palade GE. 1953. Fine structure of blood capillaries. J Appl Phys 24: 1424.
Park DY, Lee J, Kim J, Kim K, Hong S, Han S, Kubota Y, Augustin HG, Ding L, Kim JW, et al. 2017. Plastic roles of pericytes in the blood-retinal barrier. Nat Commun 8: 15296.

Parrish KE, Cen L, Murray J, Calligaris D, Kizilbash S, Mittapalli RK, Carlson BL, Schroeder MA, Sludden J, Boddy AV, et al. 2015. Efficacy of PARP inhibitor rucaparib in orthotopic glioblastoma xenografts is limited by ineffective drug penetration into the central nervous system. Mol Cancer Ther 14: 2735-2743.

Phatnani H, Maniatis T. 2015. Astrocytes in neurodegenerative disease. Cold Spring Harb Perspect Biol 7: a020628.

Potente M, Mäkinen T. 2017. Vascular heterogeneity and specialization in development and disease. Nat Rev Mol Cell Biol 18: 477-494.

Que J, Wilm B, Hasegawa H, Wang F, Bader D, Hogan BLM. 2008. Mesothelium contributes to vascular smooth muscle and mesenchyme during lung development. Proc Natl Acad Sci 105: 16626-16630.

Reese TS, Karnovsky MJ. 1967. Fine structural localization of a blood-brain barrier to exogenous peroxidase. J Cell Biol 34: 207-217.

Reyahi A, Nik AM, Ghiami M, Gritli-Linde A, Pontén F, Johansson BR, Carlsson P. 2015. Foxf2 is required for brain pericyte differentiation and development and maintenance of the blood- brain barrier. Dev Cell 34: 19-32.

Rössler K, Neuchrist C, Kitz K, Scheiner O, Kraft D, Lassmann H. 1992. Expression of leucocyte adhesion molecules at the human blood-brain barrier (BBB). J Neurosci Res 31: 365-374.

Rymo SF, Gerhardt H, Wolfhagen Sand F, Lang R, Uv A, Betsholtz C. 2011. A two-way communication between microglial cells and angiogenic sprouts regulates angiogenesis in aortic ring cultures. PLOS ONE 6: e15846.

Ryu JK, McLarnon JG. 2009. A leaky blood-brain barrier, fibrinogen infiltration and microglial reactivity in inflamed Alzheimer's disease brain. J Cell Mol Med 13: 2911-2925.

Satchell SC, Braet F. 2009. Glomerular endothelial cell fenestrations: an integral component of the glomerular filtration barrier. Am J Physiol Renal Physiol 296: F947-F956.

Saunders NR, Liddelow SA, Dziegielewska KM. 2012. Barrier mechanisms in the developing brain. Front Pharmacol 3: 46.

Saunders NR, Dziegielewska KM, Møllgård K, Habgood MD. 2015. Markers for blood-brain barrier integrity: how appropriate is Evans blue in the twenty-first century and what are the alternatives? Front Neurosci 9: 385.

Schneeberger-Keeley EE, Karnovsky MJ. 1968. The ultrastructural basis of alveolar-capillary membrane permeability to peroxidase used as a tracer. J Cell Biol 37: 781-793.

Schulz C, Gomez Perdiguero E, Chorro L, Szabo-Rogers H, Cagnard N, Kierdorf K, Prinz M, Wu B, Jacobsen SEW, Pollard JW, et al. 2012. A lineage of myeloid cells independent of Myb and hematopoietic stem cells. Science 336: 86-90.

Schwabe T, Bainton RJ, Fetter RD, Heberlein U, Gaul U. 2005. GPCR signaling is required for blood-brain barrier formation in Drosophila. Cell 123: 133-144.

Sedlakova R, Shivers RR, Del Maestro RF. 1999. Ultrastructure of the blood-brain barrier in the rabbit. I Submicrosc Cytol Pathol 31: 149-161.

Seo JH, Maki T, Maeda M, Miyamoto N, Liang AC, Hayakawa K, Pham L-DD, Suwa F, Taguchi A, Matsuyama T, et al. 2014. Oligodendrocyte precursor cells support blood-brain barrier integrity via TGF- $\beta$ signaling. PLOS ONE 9: e103174.

Siegenthaler JA, Choe Y, Patterson KP, Hsieh I, Li D, Jaminet SC, Daneman R, Kume T, Huang EJ, Pleasure SJ. 2013. Foxc1 is required by pericytes during fetal brain angiogenesis. Biol Open 2: 647-659. 
Sohet F, Lin C, Munji RN, Lee SY, Ruderisch N, Soung A, Arnold TD, Derugin N, Vexler ZS, Yen FT, et al. 2015. LSR/angulin-1 is a tricellular tight junction protein involved in blood-brain barrier formation. J Cell Biol 208: 703-711.

Stanimirovic DB, Friedman A. 2012. Pathophysiology of the neurovascular unit: disease cause or consequence? Cereb Blood Flow Metab 32: 1207-1221.

Stern L, Gautier R. 1918. Le passage dans le liquide cephalorachidien de substances introduites dans la circulation et leur action sur le systeme nerveux central chez les differentes especes animales. Compte rendu des seances de la Societe de Physique et d'Histoire Naturelle du Geneve 35: 91-94.

Stern L, Gautier R. 1921. Recherches sur le liquide cephalo-rachidien. Arch Int Physiol 17: 138-192.

Stewart PA, Wiley MJ. 1981a. Developing nervous tissue induces formation of blood-brain barrier characteristics in invading endothelial cells: a study using quail-chick transplantation chimeras. Dev Biol 84: 183-192.

Stewart PA, Wiley MJ. 1981b. Structural and histochemical features of the avian blood-brain barrier. I Comp Neurol 202: 157-167.

Stewart PA, Magliocco M, Hayakawa K, Farrell CL, Del Maestro RF, Girvin J, Kaufmann JC, Vinters HV, Gilbert J. 1987. A quantitative analysis of blood-brain barrier ultrastructure in the aging human. Microvasc Res 33: 270-282.

Stork T, Engelen D, Krudewig A, Silies M, Bainton RJ, Klämbt C. 2008. Organization and function of the blood-brain barrier in Drosophila. J Neurosci 28: 587-597.

Sweeney MD, Ayyadurai S, Zlokovic BV. 2016. Pericytes of the neurovascular unit: key functions and signaling pathways. Nat Neurosci 19: 771-783.

Sweeney MD, Sagare AP, Zlokovic BV. 2018. Blood-brain barrier breakdown in Alzheimer disease and other neurodegenerative disorders. Nat Rev Neurol 14: 133-150.

Taheri S, Gasparovic C, Shah NJ, Rosenberg GA. 2010. Quantitative measurement of blood-brain barrier permeability in human using dynamic contrast-enhanced MRI with fast T1 mapping. Magn Reson Med 65: 1036-1042.

Tam SJ, Richmond DL, Kaminker JS, Modrusan Z, MartinMcNulty B, Cao TC, Weimer RM, Carano RAD, van Bruggen N, Watts RJ. 2012. Death receptors DR6 and TROY regulate brain vascular development. Dev Cell 22: 403-417.

Trost A, Lange S, Schroedl F, Bruckner D, Motloch KA, Bogner B, Kaser-Eichberger A, Strohmaier C, Runge C, Aigner L, et al. 2016. Brain and retinal pericytes: origin, function and role. Front Cell Neurosci 10: 20.

Uchida Y, Ohtsuki S, Katsukura Y, Ikeda C, Suzuki T, Kamiie J, Terasaki T. 2011. Quantitative targeted absolute proteomics of human blood-brain barrier transporters and receptors. I Neurochem 117: 333-345.

Umans RA, Henson HE, Mu F, Parupalli C, Ju B, Peters JL, Lanham KA, Plavicki JS, Taylor MR. 2017. CNS angiogenesis and barriergenesis occur simultaneously. Dev Biol 425: 101-108.

Unhavaithaya Y, Orr-Weaver TL. 2012. Polyploidization of glia in neural development links tissue growth to blood-brain barrier integrity. Genes Dev 26: 31-36.

van de Haar HJ, Burgmans S, Jansen JFA, van Osch MJP, van Buchem MA, Muller M, Hofman PAM, Verhey FRJ, Backes WH. 2016a. Blood-brain barrier leakage in patients with early Alzheimer disease. Radiology 281: 527-535. van de Haar HJ, Jansen JFA, van Osch MJP, van Buchem MA, Muller M, Wong SM, Hofman PAM, Burgmans S, Verhey FRJ, Backes WH. 2016b. Neurovascular unit impairment in early Alzheimer's disease measured with magnetic resonance imaging. Neurobiol Aging 45: 190-196.

Vatine GD, Al-Ahmad A, Barriga BK, Svendsen S, Salim A, Garcia L, Garcia VJ, Ho R, Yucer N, Qian T, et al. 2017. Modeling psychomotor retardation using iPSCs from MCT8-deficient patients indicates a prominent role for the blood-brain barrier. Cell Stem Cell 20: 831-843.e5.

Venero Galanternik M, Castranova D, Gore AV, Blewett NH, Jung HM, Stratman AN, Kirby MR, Iben J, Miller MF, Kawakami K, et al. 2017. A novel perivascular cell population in the zebrafish brain. eLife 6: e24369.

Vick NA, Bigner DD. 1972. Microvascular abnormalities in virally-induced canine brain tumors. Structural bases for altered blood-brain barrier function. J Neurol Sci 17: 29-39.

Villaseñor R, Kuennecke B, Ozmen L, Ammann M, Kugler C, Grüninger F, Loetscher H, Freskgård P-O, Collin L. 2016. Region-specific permeability of the blood-brain barrier upon pericyte loss. J Cereb Blood Flow Metab 37: 3683-3694.

Waldron RL, Bryan RN. 1975. Effects of contrast agents on the blood-brain barrier: an electron microscopic study. Radiology 116: 195-198.

Wang Y, Rattner A, Zhou Y, Williams J, Smallwood PM, Nathans J. 2012. Norrin/Frizzled4 signaling in retinal vascular development and blood brain barrier plasticity. Cell 151: 1332-1344.

Wang Y, Pan L, Moens CB, Appel B. 2013. Notch3 establishes brain vascular integrity by regulating pericyte number. Development 141: 307-317.

Wilm B, Ipenberg A, Hastie ND, Burch JBE, Bader DM. 2005. The serosal mesothelium is a major source of smooth muscle cells of the gut vasculature. Development 132: 5317-5328.

Winkler EA, Bell RD, Zlokovic BV. 2011. Central nervous system pericytes in health and disease. Nat Neurosci 14: 1398-1405.

Winkler EA, Nishida Y, Sagare AP, Rege SV, Bell RD, Perlmutter D, Sengillo JD, Hillman S, Kong P, Nelson AR, et al. 2015. GLUT1 reductions exacerbate Alzheimer's disease vasculoneuronal dysfunction and degeneration. Nat Neurosci 18: 521-530.

Xie J, Farage E, Sugimoto M, Anand-Apte B. 2010. A novel transgenic zebrafish model for blood-brain and blood-retinal barrier development. BMC Dev Biol 10: 76.

Yamada E. 1955. The fine structure of the gall bladder epithelium of the mouse. I Biophys Biochem Cytol 1: 445-458.

Yamanishi E, Takahashi M, Saga Y, Osumi N. 2012. Penetration and differentiation of cephalic neural crest-derived cells in the developing mouse telencephalon. Dev Growth Differ 54: 785-800.

Zeisel A, Muñoz-Manchado AB, Codeluppi S, Lönnerberg P, La Manno G, Juréus A, Marques S, Munguba H, He L, Betsholtz C, et al. 2015. Cell types in the mouse cortex and hippocampus revealed by single-cell RNA-seq. Science 347: 1138-1142.

Zhang Y, Chen K, Sloan SA, Bennett ML, Scholze AR, O'Keeffe S, Phatnani HP, Guarnieri P, Caneda C, Ruderisch N, et al. 2014. An RNA-sequencing transcriptome and splicing database of glia, neurons, and vascular cells of the cerebral cortex. I Neurosci 34: 11929-11947.

Zhao Z, Nelson AR, Betsholtz C, Zlokovic BV. 2015. Establishment and dysfunction of the blood-brain barrier. Cell 163: 1064-1078. 


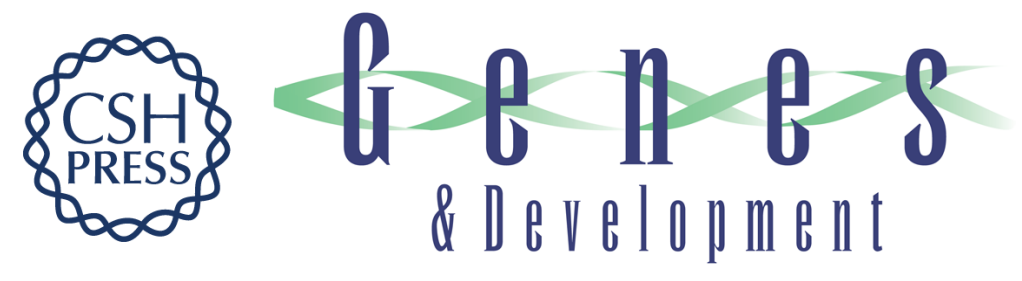

\section{Bridging barriers: a comparative look at the blood-brain barrier across organisms}

Natasha M. O'Brown, Sarah J. Pfau and Chenghua Gu

Genes Dev. 2018, 32:

Access the most recent version at doi:10.1101/gad.309823.117

\begin{tabular}{|c|c|}
\hline References & $\begin{array}{l}\text { This article cites } 155 \text { articles, } 34 \text { of which can be accessed free at: } \\
\text { http://genesdev.cshlp.org/content/32/7-8/466.full.html\#ref-list-1 }\end{array}$ \\
\hline $\begin{array}{r}\text { Creative } \\
\text { Commons } \\
\text { License }\end{array}$ & $\begin{array}{l}\text { This article is distributed exclusively by Cold Spring Harbor Laboratory Press for the first } \\
\text { six months after the full-issue publication date (see } \\
\text { http://genesdev.cshlp.org/site/misc/terms.xhtml). After six months, it is available under a } \\
\text { Creative Commons License (Attribution-NonCommercial } 4.0 \text { International), as described } \\
\text { at http://creativecommons.org/licenses/by-nc/4.0/. }\end{array}$ \\
\hline $\begin{array}{l}\text { Email Alerting } \\
\text { Service }\end{array}$ & $\begin{array}{l}\text { Receive free email alerts when new articles cite this article - sign up in the box at the top } \\
\text { right corner of the article or click here. }\end{array}$ \\
\hline
\end{tabular}

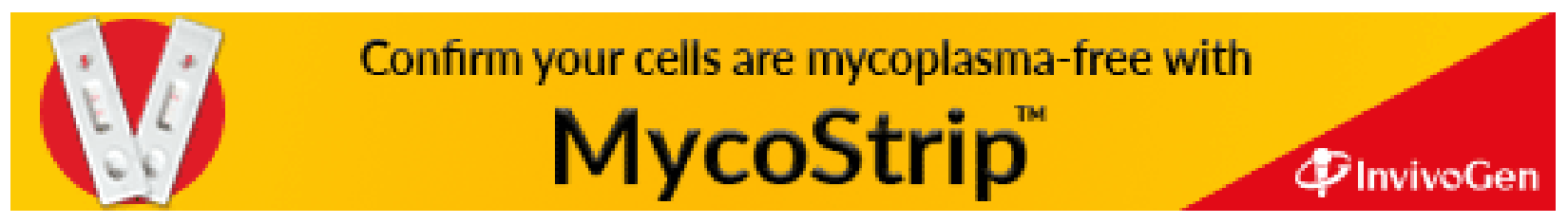

